\title{
HISTÓRIA, CIÊNCIA E ATIVISMO
}

S. C. AGUIAR*
Universidade Federal de Campina Grande
saracameloag@hotmail.com*
Artigo submetido em 07/08/2017 e aceito em $11 / 08 / 2019$
DOI: $10.15628 /$ holos.2019.6192 $^{*}$

\section{RESENHA}

DUARTE, Regina Horta (2010). A Biologia Militante: o Museu Nacional, especialização científica, divulgação do conhecimento e práticas políticas no Brasil 1926-1945. Belo Horizonte, Brasil: Editora UFMG.

A obra de Regina Horta Duarte diferentemente de discussões científicas exaustivas consiste em uma escrita prazerosa a respeito de um determinado período (1926-1945) da história do Museu Nacional do Rio de Janeiro, tendo como protagonistas os seus três membros e também cientistas, o antropólogo Edgar Roquette-Pinto, o fitobotânico Alberto José de Sampaio e o aracnólogo Cândido de Mello Leitão. Trata-se de um momento ímpar na história do Museu movido pelos seus membros que buscaram tanto a sua recriação quanto a reinvenção de sua função social, procuraram por intermédio de vários meios de comunicação atingir o grande público e, desse modo, mesclaram atividades científicas e estratégias políticas.

O livro é dividido em três capítulos e a conclusão, o primeiro é intitulado de "A voz mais alta da biologia" (p. 23), o qual relata a relação entre Roquette-Pinto, Sampaio e Mello Leitão, que além de trabalharem no Museu Nacional também contavam com outros elementos em comum em suas trajetórias, como a elaboração do anteprojeto de regulamentação da caça e da pesca no Brasil, a formação profissional no mesmo período com conteúdos semelhante na faculdade de Medicina do Rio de Janeiro que passava a contar com as novas tendências europeias influenciadas pela teoria pasteuriana que valorizava o laboratório e o conhecimento biológico e, além disso, Roquete-Pinto e Sampaio realizaram algumas viagens ainda que em momentos diferentes com Marechal Rondon pelo interior do Brasil.

Mello Leitão começou sua trajetória como zoólogo, em 1913, na Escola Superior de Agricultura e Medicina Veterinária do Rio Janeiro e, em 1916, trabalhou com Roquete-Pinto na Escola Normal do Rio de Janeiro. Já Roquete-Pinto foi professor do Museu Nacional, sócio-fundador da Academia Brasileira de Ciências - ABC, membro fundador da Associação Brasileira de EducaçãoABE e ainda participou da organização da Rádio Sociedade do Rio de Janeiro como secretário-geral. E Sampaio, em 1912, foi professor de Botânica do Museu Nacional, e assim como Roquette-Pinto também era membro da ABE e participou das atividades da Rádio Sociedade.

A busca pela renovação do enfoque científico empenhado pelos três cientistas se cruzava com os anseios políticos do governo provisório de Getúlio Vargas, isto é, a postura contrária aos 
preceitos da teoria de Darwin também representava a busca por mudança para o povo brasileiro. Mesclando ciência e política os cientistas e militantes acreditavam que a natureza era um grande organismo equilibrado, constituído por relações interdependentes e fundada no altruísmo e sociabilidade.

Conforme Duarte, em 1934, o Código de Caça e Pesca foi publicado no Diário Oficial, que se deu inicialmente a partir da redação do anteprojeto feita por Roquette-Pinto, Mello Leitão e Sampaio, o mesmo possuía uma abordagem política pública educativa, mas na fase do decreto final ganhou uma perspectiva agrícola econômica, comercial e logística. Ou seja, não era o que os cientistas esperavam uma vez que eles buscavam conter a grande caça de animais que alimentava a moda das elites que ostentavam, sobretudo peles e penas de espécies exóticas. O Código de Caça e Pesca, portanto, assumiu conotações justamente contrárias.

Tratava-se da ascensão da biologia e da emergência da população brasileira consubstanciadas na busca de soluções para problemas políticos, um cenário que resultou em grande destaque para seus idealizadores.

Já em "A miniatura da pátria", o segundo capítulo da obra (p. 73), Duarte trata da busca dos cientistas pela divulgação da preservação da natureza, no qual é relatado o acontecimento de um churrasco das forças armadas gaúchas realizado no Rio de Janeiro, e nessa ocasião Roquette-Pinto convida os soldados a assistirem vídeos educativos a respeito da fauna e da flora brasileira.

Diversos meios de comunicação passaram a ser utilizados pelos cientistas com esse intuito, como o exemplo da explicação do termo broadcasting na revista Electron, em 1926, publicada quinzenalmente pela Rádio Sociedade do Rio de Janeiro, que significa "semear ao longe" e que representava, portanto, os anseios de Roquette-Pinto, Mello leitão e Sampaio. Em seguida Duarte faz um levantamento das produções dos três cientistas presentes na Coleção Brasiliana, os três publicaram diversos livros, mas com traços comuns em suas pesquisas científicas e escritas com entusiasmo devido à revitalização do Museu Nacional que significava a divulgação dos conhecimentos que estavam sendo escritos.

Os cientistas buscaram de maneira ativa conscientizar a população brasileira para tanto tiveram apoio governamental e conseguiram ampliar a função do Museu Nacional que até então se resumia à história natural.

No último capítulo (p. 133), "Como se faz um biólogo", Duarte disserta sobre a formação da Sociedade dos Amigos do Museu Nacional, a qual se deu a partir do declínio do museu, bem como do governo provisório de Getúlio Vargas. A criação dessa sociedade consistiu em uma iniciativa de Mello Leitão e alguns colegas para zelar pelo patrimônio cultural do Museu Nacional, desse modo, Duarte enfatiza a rica produção do cientista com especialidade em aracnídeos que alcançou reconhecimento nacional e internacional. E assim como o Museu Nacional e o governo Vargas declinaram, a biologia também perdeu espaço embora tenha passado a conquistar novos lugares nas universidades brasileiras.

Por fim na conclusão (p. 163), Duarte arremata sua obra que versou sobre a inter-relação da história política e da história da ciência e que embora pontuando o caráter autoritário em função do elitismo intelectual presente na empreitada dos cientistas evitou a crítica maniqueísta aos 
mesmos, já que não são obrigados ao "racionalismo cego". Nesse sentido, Duarte ressalta a complexidade das relações entre a ciência e o poder e que por isso se deve considerar a história da ciência. E assim Duarte fez ao escrever sobre as trajetórias de Roquette-Pinto, Mello leitão e Sampaio, enfatizando a conversação profícua desses cientistas com a sociedade que articularam seus interesses científicos aos interesses sociais e políticos do país.

A obra A Biologia Militante disserta sobre as trajetórias e contribuições de três grandes cientistas em um dado momento da história ambiental, do Museu Nacional e mais especificamente da ascensão da biologia no Brasil, mostrando que a ciência também é história, pois é um fazer todo complexo de relações de poder e interesse que se inter-relacionam. Isso demostra um traço inovador de Duarte ao considerar elementos muito além do enfoque mecanicista característico da ciência, sobretudo nas ciências biológicas, e a partir disso ela consegue reunir abordagens que faz de sua obra uma escrita suscetível à leitura e compreensão por leitores de diversas áreas do conhecimento. 